\title{
Evaluation of Quality of Life and Self-Care Among Individuals with Heart Failure
}

\author{
Demet Güneş ${ }^{1 *}$ (D), Sebahat Atalıkoğlu Başkan ${ }^{1}$ (D), Necla Kasımoğlu ${ }^{1}$ (D)
}

\begin{abstract}
The objective of the research was to evaluate quality of life and self-care agency among individuals with heart failure.

Materials and Methods. The study sample consisted of 61 patients who were diagnosed with heart failure that occurred at least six months before we started our research, had no communication problems, were over 18 years old and were selected by random sampling method. The data were collected by the researcher using a face-to-face interview technique, a descriptive information form, the Short Form-36 Quality of Life Scale, and the Self-Care Agency Scale. In the analysis of the data, numbers, percentiles, means, the Kruskal-Wallis test, the Mann-Whitney $U$ test, and the Pearson correlation coefficient were used.

Results. The patients' average self-care agency score was $71.75 \pm 33.66$. The patients received the highest score on the subscale of bodily pain $(46.76 \pm 31.02)$ and the lowest score on the subscale of role limitations due to physical health problems $(19.26 \pm 32.40)$. The patients' age and disease duration were found to affect their self-care. Some quality-of-life subscales were affected by the educational, occupational and socioeconomic status, age, disease duration.
\end{abstract}

Conclusions. Patients' quality of life was found to be low, and the level of self-care agency was found to be moderate. Patients' quality of life can be improved by increasing the frequency of self-care trainings given to patients.

\section{Keywords}

Heart Failure; Nursing; Self-Care; Quality of Life

${ }^{1}$ Erzincan Binali Yıldırım University, Faculty of Health Sciences, Erzincan, Turkey

*Corresponding author: demetimm24@gmail.com

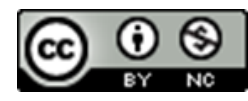

Copyright @Demet Güneş, Sebahat Atalıkoğlu Başkan, Necla Kasımoğlu, 2021

\section{Problem statement and analysis of the latest research}

Heart failure is a public health problem, which is among the major causes of mortality and morbidity, with increasing incidence in developed and developing countries, and high health care costs $[1,2]$. Heart failure is defined as the inability of the heart to pump the blood that the tissues need as a result of structural and functional cardiac impairment, or the ability to pump the blood only under high filling pressure [3]. The incidence and prevalence of heart failure vary around the world. In the United States, 500, 000 people are diagnosed with heart failure each year and 5.1 million people are reported to have heart failure. In Turkey, however, it is reported that there are over 2 million people diagnosed with heart failure [4].

Symptoms of heart failure greatly affect individuals' qual- ity of life. Symptoms such as progressive fatigue, fluid retention, decreased exercise tolerance and shortness of breath may lead to a limitation in activities of daily living, decreased quality of life, increased hospitalization frequency and premature death [5].

The main purpose of heart failure treatment is to eliminate symptoms, as well as etiological and pathogenic factors, to increase people's quality of life, and to maintain activities of daily living. In order to manage the disease effectively, non-pharmacological methods, such as adhering to lifestyle changes and medical treatment, patient and family training, improving quality of life and self-care agency can also be beneficial $[2,6]$.

Individuals diagnosed with heart failure are expected to make informed decisions when performing lifestyle behaviors, such as transitioning to a low-sodium diet, using numerous 
drugs, controlling symptoms, quitting smoking and alcohol use, exercising regularly, and monitoring daily weight. Compliance with these behaviors is of great importance in managing the disease effectively, improving health and increasing self-care agency [7]. According to Riegel and Dickson, self-care in individuals with heart failure is defined as the natural decision-making process for initiating and performing behaviors related to maintaining physiological integrity and managing symptoms [8]. Self-care in individuals with heart failure includes complying with pharmacological recommendations, consumption of a low-salt diet, quitting smoking, limiting alcohol consumption, daily monitoring of body weight, managing disease signs or symptoms [9]. Quality of life in individuals with heart failure is stated to be adversely affected by the inability to maintain their self-care at a sufficient level [10]. Quality of life is a term that refers to a sense of well-being, including being happy and being content with life, and the World Health Organization (WHO) defines quality of life as the perception of the individual's goals, expectations, criteria and social relationships within the system of values and cultural structure $[11,12]$.

Health professionals play a role in the process of protecting, improving, treating, and rehabilitating the health of all individuals in society at all times of their lives, starting before birth. The roles of health professionals in individuals with heart failure include improving their adherence to disease treatment, facilitating to cope with adverse effects of the disease and treatment, improving their self-care agency, maintaining and enhancing their quality of life [13].

The objective of the research was to evaluate quality of life and self-care abilities in individuals with heart failure.

\section{Materials and Methods}

\section{Type, Population and Sample of the Research}

The population of this descriptive research was composed of patients treated in the Cardiology Clinic and Coronary Intensive Care Unit of a University Hospital in Turkey between September 2017 and January 2018. The sample of the study consisted of 61 patients who were diagnosed with heart failure that occurred at least six months before we started our research, had no communication problems, were over 18 years old and were selected by random sampling method.

\section{Data Collection}

The study data were collected using the face-to-face interview technique with the patients in the sample. As the data collection instruments in the study, descriptive information form, containing socio-demographic data, Short Form-36 (SF-36) quality of life scale, and self-care agency scale were used.

\section{Descriptive Information Form}

The descriptive information form was prepared by the researcher and consisted of 9 items related to age, gender, marital and educational status, occupational and socioeconomic status, presence of a caregiver, smoking status and the time of diagnosis of the disease.

\section{Short Form-36 General Quality of Life Survey}

The Turkish study of the validity and reliability of the SF-36 survey, developed by Rand Corporation, was conducted by Koçyiğit et al. [14]. The survey consists of 36 items, which measure 8 dimensions. These subscales are physical functioning (10 items), social functioning ( 2 items), role limitations due to physical health problems (4 items), role limitations due to emotional problems (3 items), mental health (5 items), energy/vitality (4 items), bodily pain ( 2 items) and general health perception ( 5 items). The subscales rate health from 0 to 100: 0 indicates the worst health condition, while 100 points refer to the best health condition [14].

\section{Self-Care Agency Scale}

The Turkish study of the validity and reliability of the selfcare agency scale, which was developed by Kearney and Fleischer [15], was conducted by Nahçivan [16]. The 5-point Likert-type scale consists of 35 items, and each item is rated from 0 to 4 , with a score of 0 for "very characteristic", 1 for "somewhat characteristic", 2 for "no opinion", 3 for "somewhat uncharacteristic", or 4 for "very uncharacteristic". On the scale, 8 items $(3,6,9,13,19,22,26$ and 31) are reverse coded. The lowest score is 35 , while 140 is the highest score. The highest score indicates the highest degree of self-care agency.

\section{Data Analysis and Evaluation}

In the analysis of the data, numbers, percentiles, mean, the Kruskal-Wallis test, the Mann-Whitney U test and the Pearson correlation coefficient were used. As an advanced analysis, the LSD (Least Significant Difference) was used in cases where the variances were homogeneous, and Dunnett $\mathrm{C}$ was used for the non-homogeneous variance [17].

\section{Results}

The average patients' age was $71.57 \pm 8.59$ years; $67.2 \%$ of patients were males; $41 \%$ of patients were illiterate; $91.8 \%$ of patients were married; $47.5 \%$ of patients were non-smokers; $70.5 \%$ of patients received care by their spouse. Among them, $72.1 \%$ of patients had moderate socioeconomic status; $73.8 \%$ of patients were retired; $49.2 \%$ of patients were diagnosed with heart failure at least 25 months before the research started.

The patients' average self-care agency score was $71.75 \pm 33.66$. The patients received the highest score on the subscale of bodily pain $(46.76 \pm 31.02)$ and the lowest score on the subscale of role limitations due to physical health problems (19.26 \pm 32.40$)$ (Table 1). 
Table 1. Distribution of the patients' scores on the self-care agency scale, quality of life scale and its subscales ( $\mathrm{n}=61)$.

\begin{tabular}{lccccc}
\hline Scales and subscales & $\mathrm{n}$ & Min. & Max. & Mean & SD \\
\hline Self-care agency & 61 & 12 & 132 & 71.75 & 33.66 \\
Quality of life subscales & & & & & \\
•Physical Functioning & 61 & 0 & 100 & 31.56 & 30.15 \\
• Role limitations due to physical health problems & 61 & 0 & 100 & 19.26 & 32.40 \\
$\bullet$ Role limitations due to emotional problems & 61 & 0 & 100 & 32.76 & 27.53 \\
$\bullet$ Social functioning & 61 & 0 & 100 & 39.14 & 28.82 \\
$\bullet$ Mental health & 61 & 0 & 84 & 46.30 & 18.95 \\
$\bullet$ Energy/vitality & 61 & 0 & 80 & 31.87 & 17.94 \\
$\bullet$ Bodily pain & 61 & 0 & 100 & 46.76 & 31.02 \\
$\bullet$ General perception of health & 61 & 0 & 85 & 20.86 & 18.44 \\
\hline
\end{tabular}

Table 2. Distribution of the patients' scores on the self-care agency scale, quality of life scale and its subscales, according to their descriptive characteristics ( $\mathrm{n}=61$ ).

\begin{tabular}{|c|c|c|c|c|c|c|c|c|c|c|}
\hline \multirow[b]{2}{*}{ Introductory characteristics } & \multirow[b]{2}{*}{$\mathrm{n}(\%)$} & \multirow[b]{2}{*}{$\begin{array}{c}\text { Self-care } \\
\text { agency scale }\end{array}$} & \multicolumn{8}{|c|}{ Quality of Life Scale Subscales } \\
\hline & & & $\begin{array}{l}\text { Physical } \\
\text { functioning }\end{array}$ & $\begin{array}{c}\text { Role } \\
\text { limitations } \\
\text { due to } \\
\text { physical } \\
\text { health } \\
\text { problems }\end{array}$ & $\begin{array}{c}\text { Role } \\
\text { limitations } \\
\text { due to } \\
\text { emotional } \\
\text { problems }\end{array}$ & $\begin{array}{c}\text { Social } \\
\text { functioning }\end{array}$ & $\begin{array}{l}\text { Mental } \\
\text { health }\end{array}$ & $\begin{array}{l}\text { Energy/ } \\
\text { vitality }\end{array}$ & Bodily pain & $\begin{array}{l}\text { General } \\
\text { perception of } \\
\text { health }\end{array}$ \\
\hline Age $\mathrm{X} \pm \mathrm{SD}$ : & & $\mathrm{r}=-0.230$ & $\mathrm{r}=-0.383$ & $\mathrm{r}=-0.072$ & $\mathrm{r}=-0.071$ & $\mathrm{r}=-0.240$ & $\mathrm{r}=0.019$ & $\mathrm{r}=-0.061$ & $\mathrm{r}=-0.047$ & $\mathrm{r}=-0.198$ \\
\hline $71.57 \pm 8.59$ & & $\mathrm{p}=\mathbf{0 . 0 3 7}$ & $\mathrm{p}=0.001$ & $\mathrm{p}=0.291$ & $\mathrm{p}=0.292$ & $p=0.031$ & $\mathrm{p}=0.442$ & $\mathrm{p}=0.319$ & $\mathrm{p}=0.361$ & $\mathrm{p}=0.063$ \\
\hline \multicolumn{11}{|l|}{ Gender } \\
\hline Female & $20(32.8)$ & $73.60 \pm 35.43$ & $34.50 \pm 34.83$ & $26.25 \pm 39.30$ & $38.31 \pm 29.16$ & $43.75 \pm 31.28$ & $50.00 \pm 22.20$ & $36.25 \pm 20.06$ & $50.88 \pm 31.54$ & $23.00 \pm 19.22$ \\
\hline Male & $41(67.2)$ & $70.85 \pm 33.07$ & $30.12 \pm 27.94$ & $15.85 \pm 28.37$ & $30.05 \pm 26.65$ & $36.89 \pm 27.66$ & $44.49 \pm 17.16$ & $29.73 \pm 16.66$ & $44.76 \pm 30.95$ & $19.82 \pm 18.20$ \\
\hline Test and Significance & & $\begin{array}{c}\mathrm{U}=408.000 \\
\mathrm{p}=0.975\end{array}$ & $\begin{array}{c}\mathrm{U}=389.000 \\
\mathrm{p}=0.745\end{array}$ & $\begin{array}{c}\mathrm{U}=376.000 \\
\mathrm{p}=0.545\end{array}$ & $\begin{array}{c}\mathrm{U}=350.000 \\
\mathrm{p}=0.321\end{array}$ & $\begin{array}{c}\mathrm{U}=358.500 \\
\mathrm{p}=0.424\end{array}$ & $\begin{array}{c}\mathrm{U}=329.500 \\
\mathrm{p}=0.214\end{array}$ & $\begin{array}{c}\mathrm{U}=329.500 \\
\mathrm{p}=0.213\end{array}$ & $\begin{array}{c}\mathrm{U}=362.000 \\
\mathrm{p}=0.459\end{array}$ & $\begin{array}{c}\mathrm{U}=367.000 \\
\mathrm{p}=0.504\end{array}$ \\
\hline \multicolumn{11}{|l|}{ Educational Status } \\
\hline Illiterate & $25(41.0)$ & $59.60 \pm 30.43$ & $25.00 \pm 31.19$ & $20.00 \pm 32.27$ & $33.30 \pm 28.85$ & $38.50 \pm 29.74$ & $46.88 \pm 19.61$ & $31.20 \pm 15.70$ & $55.50 \pm 28.17$ & $18.20 \pm 17.55$ \\
\hline Literate & $14(23.0)$ & $81.93 \pm 34.82$ & $42.86 \pm 29.14$ & $25.00 \pm 33.97$ & $35.68 \pm 20.50$ & $53.57 \pm 29.59$ & $55.14 \pm 20.04$ & $43.57 \pm 22.82$ & $60.71 \pm 34.38$ & $22.14 \pm 16.37$ \\
\hline Primary school graduate & 15 (24.6) & $82.87 \pm 36.77$ & $37.67 \pm 29.39$ & $16.67 \pm 34.93$ & $28.87 \pm 30.50$ & $37.50 \pm 25.88$ & $38.93 \pm 17.00$ & $26.27 \pm 15.04$ & $26.50 \pm 21.73$ & $22.83 \pm 22.34$ \\
\hline Secondary school graduate & $4(6.6)$ & $62.50 \pm 28.08$ & $11.25 \pm 11.09$ & $00.00 \pm 00.00$ & $24.98 \pm 16.65$ & $9.38 \pm 11.97$ & $37.00 \pm 8.87$ & $18.75 \pm 8.54$ & $15.63 \pm 25.03$ & $15.00 \pm 17.80$ \\
\hline High school graduate & $3(4.9)$ & $82.33 \pm 22.85$ & $30.00 \pm 36.06$ & $25.00 \pm 43.30$ & $44.43 \pm 50.92$ & $25.00 \pm 12.50$ & $49.33 \pm 16.17$ & $28.33 \pm 7.64$ & $51.67 \pm 5.77$ & $35.00 \pm 17.32$ \\
\hline Test and Significance & & $\begin{array}{c}\mathrm{KW}=7.601 \\
\mathrm{p}=0.107\end{array}$ & $\begin{array}{c}\mathrm{KW}=7.160 \\
\mathrm{p}=0.128\end{array}$ & $\begin{array}{c}\mathrm{KW}=3.795 \\
\mathrm{p}=0.434\end{array}$ & $\begin{array}{c}\mathrm{KW}=1.262 \\
\mathrm{p}=0.868\end{array}$ & $\begin{array}{c}\mathrm{KW}=9.127 \\
\mathrm{p}=0.058\end{array}$ & $\begin{array}{c}\mathrm{KW}=5.931 \\
\mathrm{p}=0.204\end{array}$ & $\begin{array}{c}\mathrm{KW}=7.254 \\
\mathrm{p}=0.123\end{array}$ & $\begin{array}{c}\mathrm{KW}=15.767 \\
\mathbf{p}=\mathbf{0 . 0 0 3}\end{array}$ & $\begin{array}{c}\mathrm{KW}=3.858 \\
\mathrm{p}=0.426\end{array}$ \\
\hline \multicolumn{11}{|l|}{ Marital Status } \\
\hline Married & $56(91.8)$ & $71.04 \pm 34.88$ & $30.71 \pm 29.39$ & $18.75 \pm 32.77$ & $32.11 \pm 26.92$ & $38.84 \pm 28.37$ & $45.57 \pm 18.73$ & $31.59 \pm 18.30$ & $47.01 \pm 31.37$ & $20.04 \pm 18.29$ \\
\hline Single & $5(8.2)$ & $79.80 \pm 13.33$ & $41.00 \pm 40.37$ & $25.00 \pm 61.62$ & $39.98 \pm 36.52$ & $42.50 \pm 32.08$ & $54.40 \pm 21.84$ & $35.00 \pm 14.58$ & $44.00 \pm 29.82$ & $30.00 \pm 19.69$ \\
\hline Test and Significance & & $\begin{array}{c}\mathrm{U}=129.000 \\
\mathrm{p}=0.772\end{array}$ & $\begin{array}{c}\mathrm{U}=117.000 \\
\mathrm{p}=0.542\end{array}$ & $\begin{array}{c}\mathrm{U}=111.000 \\
\mathrm{p}=0.377\end{array}$ & $\begin{array}{c}\mathrm{U}=126.500 \\
\mathrm{p}=0.702\end{array}$ & $\begin{array}{c}\mathrm{U}=131.000 \\
\mathrm{p}=0.811\end{array}$ & $\begin{array}{c}\mathrm{U}=97.000 \\
\mathrm{p}=0.256\end{array}$ & $\begin{array}{c}\mathrm{U}=119.000 \\
\mathrm{p}=0.579\end{array}$ & $\begin{array}{c}\mathrm{U}=135.500 \\
\mathrm{p}=0.905\end{array}$ & $\begin{array}{c}\mathrm{U}=94.500 \\
\mathrm{p}=0.226\end{array}$ \\
\hline
\end{tabular}


Table 2. Distribution of the patients' scores on the self-care agency scale, quality of life scale and its subscales, according to their descriptive characteristics ( $\mathrm{n}=61$ ).

\begin{tabular}{|c|c|c|c|c|c|c|c|c|c|c|}
\hline \multirow[b]{2}{*}{ Introductory characteristics } & \multirow[b]{2}{*}{$\mathrm{n}(\%)$} & \multirow[b]{2}{*}{$\begin{array}{c}\text { Self-care } \\
\text { agency scale }\end{array}$} & \multicolumn{8}{|c|}{ Quality of Life Scale Subscales } \\
\hline & & & $\begin{array}{l}\text { Physical } \\
\text { functioning }\end{array}$ & $\begin{array}{c}\text { Role } \\
\text { limitations } \\
\text { due to } \\
\text { physical } \\
\text { health } \\
\text { problems }\end{array}$ & $\begin{array}{l}\text { Role } \\
\text { limitations } \\
\text { due to } \\
\text { emotional } \\
\text { problems }\end{array}$ & $\begin{array}{c}\text { Social } \\
\text { functioning }\end{array}$ & $\begin{array}{l}\text { Mental } \\
\text { health }\end{array}$ & $\begin{array}{l}\text { Energy/ } \\
\text { vitality }\end{array}$ & Bodily pain & $\begin{array}{c}\text { General } \\
\text { perception o } \\
\text { health }\end{array}$ \\
\hline \multicolumn{11}{|l|}{ Occupational Status } \\
\hline Unemployed & $4(6.6)$ & $76.00 \pm 15.47$ & $58.75 \pm 36.37$ & $25.00 \pm 50.00$ & $25.00 \pm 50.00$ & $46.88 \pm 48.28$ & $28.00 \pm 9.80$ & $22.50 \pm 6.45$ & $23.75 \pm 9.24$ & $13.75 \pm 6.29$ \\
\hline Retired & $45(73.8)$ & $72.58 \pm 34.34$ & $29.00 \pm 29.38$ & $18.89 \pm 31.15$ & $34.04 \pm 27.04$ & $33.33 \pm 25.14$ & $44.44 \pm 18.67$ & $29.76 \pm 17.71$ & $45.06 \pm 31.70$ & $19.61 \pm 17.96$ \\
\hline Other & $12(19.6)$ & $67.25 \pm 36.99$ & $32.08 \pm 29.11$ & $18.75 \pm 33.92$ & $30.53 \pm 22.26$ & $58.33 \pm 28.37$ & $59.33 \pm 14.75$ & $42.92 \pm 17.51$ & $60.83 \pm 28.01$ & $27.92 \pm 21.79$ \\
\hline Test and Significance & & $\begin{array}{c}\mathrm{KW}=0.040 \\
\mathrm{p}=0.841\end{array}$ & $\begin{array}{c}\mathrm{KW}=3.343 \\
\mathrm{p}=0.067\end{array}$ & $\begin{array}{c}\mathrm{KW}=0.075 \\
\mathrm{p}=0.785\end{array}$ & $\begin{array}{c}\mathrm{KW}=1.195 \\
\mathrm{p}=0.274\end{array}$ & $\begin{array}{c}\mathrm{KW}=0.088 \\
\mathrm{p}=0.767\end{array}$ & $\begin{array}{c}\mathrm{KW}=3.996 \\
\mathbf{p}=\mathbf{0 . 0 4 6}\end{array}$ & $\begin{array}{c}\mathrm{KW}=0.781 \\
\mathrm{p}=0.377\end{array}$ & $\begin{array}{c}\mathrm{KW}=1.293 \\
\mathrm{p}=0.256\end{array}$ & $\begin{array}{c}\mathrm{KW}=0.077 \\
\mathrm{p}=0.782\end{array}$ \\
\hline \multicolumn{11}{|l|}{ Socioeconomic Status } \\
\hline Poor & $14(23.0)$ & $63.29 \pm 36.20$ & $39.64 \pm 34.89$ & $23.21 \pm 38.56$ & $33.31 \pm 29.22$ & $58.04 \pm 32.75$ & $51.71 \pm 18.19$ & $39.29 \pm 16.16$ & $53.21 \pm 27.71$ & $22.86 \pm 20.91$ \\
\hline Moderate & $44(72.1)$ & $73.80 \pm 33.80$ & $29.66 \pm 29.38$ & $18.75 \pm 31.50$ & $34.06 \pm 27.35$ & $32.67 \pm 25.03$ & $44.27 \pm 18.85$ & $29.52 \pm 17.84$ & $44.77 \pm 32.01$ & $19.94 \pm 18.03$ \\
\hline Good & $3(4.9)$ & $81.33 \pm 16.62$ & $21.67 \pm 10.41$ & $8.33 \pm 14.43$ & $11.10 \pm 19.23$ & $45.83 \pm 31.46$ & $50.67 \pm 25.72$ & $31.67 \pm 24.66$ & $45.83 \pm 38.27$ & $25.00 \pm 17.32$ \\
\hline Test and Significance & & $\begin{array}{c}\mathrm{KW}=1.384 \\
\mathrm{p}=0.500\end{array}$ & $\begin{array}{c}\mathrm{KW}=1.152 \\
\mathrm{p}=0.562\end{array}$ & $\begin{array}{c}\mathrm{KW}=0.109 \\
\mathrm{p}=0.947\end{array}$ & $\begin{array}{c}\mathrm{KW}=2.199 \\
\mathrm{p}=0.333\end{array}$ & $\begin{array}{c}\mathrm{KW}=6.577 \\
\mathbf{p}=\mathbf{0 . 0 3 7}\end{array}$ & $\begin{array}{c}\mathrm{KW}=2.145 \\
\mathrm{p}=0.342\end{array}$ & $\begin{array}{c}\mathrm{KW}=4.085 \\
\mathrm{p}=0.130\end{array}$ & $\begin{array}{c}\mathrm{KW}=1.176 \\
\mathrm{p}=0.555\end{array}$ & $\begin{array}{c}\mathrm{KW}=0.724 \\
\mathrm{p}=0.696\end{array}$ \\
\hline \multicolumn{11}{|l|}{ Smoking Status } \\
\hline Yes & $5(8.2)$ & $47.60 \pm 32.88$ & $32.00 \pm 35.11$ & $35.00 \pm 48.73$ & $46.64 \pm 38.00$ & $25.00 \pm 23.39$ & $48.00 \pm 4.90$ & $28.00 \pm 13.51$ & $42.50 \pm 30.05$ & $23.00 \pm 20.49$ \\
\hline No & $29(47.5)$ & $73.41 \pm 35.71$ & $35.69 \pm 30.73$ & $18.97 \pm 34.50$ & $32.16 \pm 27.42$ & $42.24 \pm 28.62$ & $47.59 \pm 22.46$ & $34.14 \pm 18.95$ & $44.91 \pm 28.93$ & $19.31 \pm 17.10$ \\
\hline Quit & $27(44.3)$ & $74.44 \pm 30.87$ & $27.04 \pm 29.16$ & $16.67 \pm 26.85$ & $30.83 \pm 26.00$ & $38.43 \pm 30.01$ & $44.59 \pm 16.63$ & $30.15 \pm 17.79$ & $49.54 \pm 34.12$ & $22.13 \pm 20.01$ \\
\hline Test and Significance & & $\begin{array}{c}\mathrm{KW}=3.266 \\
\mathrm{p}=0.195\end{array}$ & $\begin{array}{c}\mathrm{KW}=1.705 \\
\mathrm{p}=0.426\end{array}$ & $\begin{array}{c}\mathrm{KW}=0.615 \\
\mathrm{p}=0.735\end{array}$ & $\begin{array}{c}\mathrm{KW}=0.901 \\
\mathrm{p}=0.637\end{array}$ & $\begin{array}{c}\mathrm{KW}=1.705 \\
\mathrm{p}=0.426\end{array}$ & $\begin{array}{c}\mathrm{KW}=0.864 \\
\mathrm{p}=0.649\end{array}$ & $\begin{array}{c}\mathrm{KW}=1.427 \\
\mathrm{p}=0.490\end{array}$ & $\begin{array}{c}\mathrm{KW}=0.192 \\
\mathrm{p}=0.908\end{array}$ & $\begin{array}{c}\mathrm{KW}=0.292 \\
\mathrm{p}=0.864\end{array}$ \\
\hline \multicolumn{11}{|l|}{ Caregiver } \\
\hline Spouse & $43(70.5)$ & $69.42 \pm 31.59$ & $26.98 \pm 25.52$ & $15.70 \pm 27.83$ & $30.20 \pm 27.01$ & $39.53 \pm 27.81$ & $45.86 \pm 17.62$ & $31.37 \pm 17.64$ & $48.90 \pm 32.14$ & $18.31 \pm 17.01$ \\
\hline Children & $12(19.7)$ & $75.08 \pm 38.03$ & $39.58 \pm 34.74$ & $35.42 \pm 44.54$ & $41.63 \pm 25.12$ & $40.63 \pm 32.48$ & $52.33 \pm 24.15$ & $36.67 \pm 22.50$ & $48.13 \pm 30.15$ & $30.00 \pm 23.45$ \\
\hline Carer & $6(9.8)$ & $81.83 \pm 42.86$ & $48.33 \pm 45.90$ & $12.50 \pm 30.62$ & $33.32 \pm 36.51$ & $33.33 \pm 33.23$ & $37.33 \pm 15.32$ & $25.83 \pm 5.85$ & $28.75 \pm 20.78$ & $20.83 \pm 13.57$ \\
\hline Test and Significance & & $\begin{array}{c}\mathrm{KW}=1.027 \\
\mathrm{p}=0.599\end{array}$ & $\begin{array}{c}\mathrm{KW}=2.657 \\
\mathrm{p}=0.265\end{array}$ & $\begin{array}{c}\mathrm{KW}=3.621 \\
\mathrm{p}=0.164\end{array}$ & $\begin{array}{c}\mathrm{KW}=4.713 \\
\mathrm{p}=0.095\end{array}$ & $\begin{array}{c}\mathrm{KW}=0.175 \\
\mathrm{p}=0.916\end{array}$ & $\begin{array}{c}\mathrm{KW}=2.207 \\
\mathrm{p}=0.332\end{array}$ & $\begin{array}{c}\mathrm{KW}=0.598 \\
\mathrm{p}=0.742\end{array}$ & $\begin{array}{c}\mathrm{KW}=0.106 \\
\mathrm{p}=0.948\end{array}$ & $\begin{array}{c}\mathrm{KW}=3.828 \\
\mathrm{p}=0.147\end{array}$ \\
\hline \multicolumn{11}{|l|}{ Disease duration } \\
\hline 6-12 months & $20(32.8)$ & $86.00 \pm 33.02$ & $42.25 \pm 25.47$ & $15.00 \pm 27.39$ & $33.31 \pm 24.17$ & $38.13 \pm 26.43$ & $52.60 \pm 16.68$ & $36.45 \pm 18.87$ & $46.50 \pm 31.51$ & $26.25 \pm 19.32$ \\
\hline 13-24 months & $11(18.0)$ & $44.10 \pm 29.81$ & $34.55 \pm 31.26$ & $38.64 \pm 40.87$ & $48.44 \pm 22.90$ & $65.91 \pm 18.62$ & $50.18 \pm 10.64$ & $39.01 \pm 14.46$ & $71.82 \pm 19.43$ & $19.55 \pm 22.07$ \\
\hline 25 months and over & $30(49.2)$ & $72.40 \pm 29.88$ & $23.33 \pm 31.08$ & $15.00 \pm 30.51$ & $26.65 \pm 29.54$ & $30.00 \pm 27.97$ & $40.67 \pm 21.35$ & $26.17 \pm 17.10$ & $37.75 \pm 29.79$ & $17.75 \pm 16.14$ \\
\hline Test and Significance & & $\begin{array}{c}\mathrm{KW}=11.398 \\
\mathbf{p}=\mathbf{0 . 0 0 3}\end{array}$ & $\begin{array}{c}\mathrm{KW}=8.394 \\
\mathbf{p}=\mathbf{0 . 0 1 5}\end{array}$ & $\begin{array}{c}\mathrm{KW}=6.856 \\
\mathbf{p}=\mathbf{0 . 0 3 2}\end{array}$ & $\begin{array}{c}\mathrm{KW}=6.859 \\
\mathbf{p}=\mathbf{0 . 0 3 2}\end{array}$ & $\begin{array}{c}\mathrm{KW}=13.344 \\
\mathbf{p}=\mathbf{0 . 0 0 1}\end{array}$ & $\begin{array}{c}\mathrm{KW}=5.307 \\
\mathrm{p}=0.070\end{array}$ & $\begin{array}{c}\mathrm{KW}=7.735 \\
\mathbf{p}=\mathbf{0 . 0 2 1}\end{array}$ & $\begin{array}{c}\mathrm{KW}=10.698 \\
\mathbf{p}=\mathbf{0 . 0 0 5}\end{array}$ & $\begin{array}{c}\mathrm{KW}=3.572 \\
\mathrm{p}=0.168\end{array}$ \\
\hline
\end{tabular}

Notes: KW - the Kruskal-Wallis test, U - the Mann-Whitney U test, $\mathrm{r}$ - the Pearson correlation coefficient. 
According to Table 2, there was a weak negative correlation between the patients' age, the self-care agency, and the physical and social functioning subscales. In addition, there was a statistically significant difference between the subscales of bodily pain in terms of patients' educational status; the average score of the literate subscale was higher than that of the illiterate one.

Significant differences were found between the subscales of social functioning according to the socioeconomic status of patients included in the study; the average score of individuals with good socioeconomic status was high.

There were found significant differences between the subscales of mental health according to the occupational status; the average score of retired individuals was higher than that of employees.

There was found a statistically significant difference between the subscales, except for the subscales of mental health and general perception of health, depending on the duration of the illness. Those with disease duration of 13-24 months had significantly higher scores on the subscales of social functioning, role limitations due to physical health and emotional problems, and bodily pain than those with disease duration of 6-12 to 25 months and over.

There was a significant, weak positive correlation between the subscale of physical functioning and self-care agency, and a significant, moderate positive correlation between the subscale of general health perception and self-care agency among patients included in the study (Table 3 ).

Table 3. Relationship between the patients' self-care agency scale and quality of life subscales.

\begin{tabular}{lcc}
\hline \multirow{2}{*}{ Quality of Life Scale } & \multicolumn{2}{c}{ Self-Care Agency Scale } \\
\cline { 2 - 3 } & $\mathrm{r}$ & $\mathrm{p}$ \\
\hline $\begin{array}{l}\text { Physical functioning } \\
\text { Role limitations due to physical } \\
\text { health problems }\end{array}$ & 0.309 & $\mathbf{0 . 0 1 5}$ \\
Role limitations due to emotional \\
problems
\end{tabular}

Notes: $\mathrm{r}$ - the Pearson correlation coefficient, ${ }^{*}-\mathrm{p}<0.05$, $* *-\mathrm{p}<0.01$

\section{Discussion}

Heart failure is a major life-threatening health problem due to the need for lifelong treatment, frequent hospitalizations, complex and expensive treatment practices [18]. It is emphasized that self-care is important for patients with heart failure for the success of treatment and decrease in the frequency of hospitalizations [19]. Patients who have self-care agency have been reported to be hospitalized infrequently and have lesser hospitalization costs, mortality and morbidity rates [8]. In this study, the patients' self-care ability was found to be moderate; age and disease duration were found to affect self-care. $\mathrm{Nu}$ merous studies involving individuals with heart failure have supported our findings as well, reporting patients' self-care agency as moderate $[20,21]$. Contrary to our findings, there have been some studies involving individuals with heart failure having low self-care agency $[6,22]$.

Advancing age leads to the increased incidence of chronic diseases, limitations in physical functioning, psychosocial problems and need for social support. The patients' age has been found to increase, and self-care agency to decrease [26].

In our study, gender was not found to affect self-care agency. The same results have been obtained by Asgar Pour et al., Akbiyık et al. [23, 24].

According to the literature, the concept of health is influenced by the profession, the educational and socioeconomic status, the presence of a caregiver in the individual's family [25]. Patients with a high level of education, good socioeconomic status and strong social support system are expected to have higher self-care agencies alongside with high levels of awareness about their health. Contrary to the literature, the profession, the educational and socioeconomic status, the presence of a caregiver were found not to affect self-care agency. Similar results have been obtained in the studies conducted by Ermiş and Tegegn et al. [26, 27]. Contrary to our findings, some studies have found that patients with high educational status had higher self-care agency [28, 29]. It can be stated that having a spouse and children as a caregiver is supportive in acquiring self-care behaviors. However, there was no significant difference between self-care and caregiving in our study. A study conducted by \&Ccedil; elikt\&uuml; rk in 2016 that involved patients with heart transplants has found that the status of patients receiving help did not affect their self-care behavior [30].

In our study, the duration of the disease was found to affect individuals' self-care agency. According to Dickson et al., the experience of disease increased the patients' compliance with self-care behaviors [31]. The findings of another study conducted by Akbiyık et al., showed that the duration of the disease did not affect self-care agency [24].

It impairs quality of life adversely affecting physical, mental, and social life of patients with periods of exacerbations and regressions. In our study, we found that individuals with heart failure had low quality of life. Similar results have been obtained in other studies [32, 33].

Patients' physical and social functioning decreased with age. According to Mo Y et al., the frequency of hospitalizations increased with age that negatively affected quality of life [34].

The patient's educational level was found to affect the subscale of bodily pain and the mean literate score was found to be higher than the mean illiterate score. Similar to our study, a study conducted by Uslu has found that the educational status affected the subscale of bodily pain and the average 
score of this subscale increased with the increase in the level of education [35]. Individuals with high level of education are believed to be able to manage stress and pain by exerting positive health behaviors, taking more responsibility for their own health, and willing to learn strategies for managing disease symptoms.

The patients' profession was found to affect the subscale of mental health and the average score among retired patients was higher than that among unemployed patients. People who experience heart failure and its symptoms as a chronic disease can go through negative experiences, such as being unable to continue their working life due to restrictions on the freedom of physical movements, to adapt to social environment, to fulfill their roles in the family, as well as due to the emergence of economic problems. This is believed to affect their quality of life causing psychosocial disorders in patients and their families over time.

The patient's socioeconomic status affected the subscale of social functioning; those with a good socioeconomic status had higher average score than those with a poor socioeconomic status. Contrary to our study, a study conducted by Uslu has found that the socioeconomic status did not affect the subscale of social functioning [35]. Individuals with a good socioeconomic status can be considered to have good quality of life within the scope of personal social sphere, as they are able to receive better care in public/private health care institutions, and adhere to the recommended treatments, without being affected by the problems caused by chronic disease.

The duration of disease affected the subscales of social functioning, role limitations due to physical health and emotional problems, and bodily pain. The indicators in those with disease duration of 13-24 months were higher than those in patients with disease duration of 25 months or more. In parallel with the study findings, another study has stated that the duration of disease affected all subscales of quality of life [35]. As disease duration increases, the inability to perform the activities of daily living, increased diseases symptoms, fatigue, and inability to cope with symptoms due to physical constraints can be considered as a negative impact on patients' quality of life.

There was found a significant positive correlation between the physical functions of patients' self-care ability, which is one of the subscales of quality of life, and their general health perception. Having good physical functioning is believed to promote individuals with heart failure to perform the activities of daily living easily and to increase their self-care capacity. Perception of health is defined as the combination of personal feelings, thoughts, prejudices, and expectations about own health. Although individuals perceive themselves as healthy, despite having one or more chronic diseases, they may perceive themselves as a patient without any objective signs of illness [36]. Positive perception of own health condition by individuals with heart failure is believed to positively affect their self-care agency.

\section{Conclusions}

Patients' quality of life was found to be low, and the level of self-care agency was found to be moderate. Although patients' self-care behaviors did not vary significantly depending on the educational and marital, occupational and socioeconomic, as well as smoking status, the presence of a caregiver and gender, they did vary in terms of age and duration of illness. The patient's marital and smoking status, the presence of a caregiver and gender were found not to affect all subscales of quality of life. Self-care agency was found to increase as the subscales of physical functioning and general health perception increased.

\section{Prospects of Further Researches}

According to our results, increasing the frequency of selfcare trainings given to patients, ensuring behavior changes and repeating the trainings at regular intervals according to patients' needs will increase their quality of life. In addition, identifying the factors affecting patients' self-care agency and quality of life, and planning the necessary interventions and implementing them by the health care professionals will be effective in improving individuals' self-care agency and quality of life.

\section{Ethical Statement}

The approval of the Ethics Committee No. 07/01 dated September 28, 2017 and a written permission from the studied hospital were obtained to carry out the research. The principle of informed consent, the principle of respect for autonomy and the principle of protection of privacy and confidentiality were fulfilled during the collection of research data.

\section{Informed Consent}

Informed consent was obtained from each participant.

\section{Acknowledgements}

In this study we didn't take any foundation. The authors acknowledge the contributions of all patients who took part in the study, and thank the clerical staff of the clinic where these data were gathered.

\section{Conflict of Interest}

The authors declare that no conflicts exist.

\section{Financial Disclosure}

The authors declared no financial support.

\section{References}

[1] Kaya G, Çıtlık Sarıtaş S. Importance of exercise in controlling symptoms in patients with heart failure. Journal 
of Cardiovascular Nursing [Internet]. 2016;7(13):75-87. Available from: https://doi.org/10.5543/khd.2016.41736

[2] Özer S, Sezgin D. Self-care in heart failure. Turkish Cardiology Association Heart Failure Electronic Newsletter. 2015;7(4).

[3] Akdemir N, Canli Özer Z. Heart failure and nursing care protection from heart diseases. In: Akdemir N, Birol L, editors. Internal Diseases and Nursing Care. Ankara: Özyurt Printing; c2020. 587-595.

[4] Degertekin M, Erol C, Ergene O, Tokgozoglu L, Aksoy M, Erol MK, et al. Heart failure prevalence and predictors in Turkey (HAPPY) Çalışması. Turk Kardiyoloji Dernegi Arsivi-Archives of the Turkish Society of Cardiology [Internet]. 2012;40(4):298-308. Available from: https://doi.org/10.5543/tkda.2012.65031

[5] Ogah O, Adebayo S, Olunuga T, Durodola A. Heart failure: definition, classification, and pathophysiology - a mini-review. Nigerian Journal of Cardiology [Internet]. 2017;14(1):9. Available from: https://doi.org/10.4103/0189-7969.201913

[6] Baydemir C, Ozdamar K, Unalir A. Validity of the Turkish version of the European Heart Failure Self-Care Behavior Scale. Anadolu Kardiyoloji Dergisi/The Anatolian Journal of Cardiology [Internet]. 2013;13:573-579. Available from: https://doi.org/10.5152/akd.2013.141

[7] Schnell-Hoehn KN, Naimark BJ, Tate RB. Determinants of self-care behaviors in community-dwelling patients with heart failure. Journal of Cardiovascular Nursing [Internet]. 2009 Jan;24(1):40-47. Available from: https://doi.org/10.1097/01.JCN.0000317470.58048.7b

[8] Riegel B, Moser DK, Anker SD, Appel LJ, Dunbar SB, Grady KL, et al. Promoting self-care in persons with heart failure: a scientific statement from the american heart association. Circulation [Internet]. 2009;120(12):1141-1163. Available from: https://doi.org/10.1161/CIRCULATIONAHA.109.192628

[9] Riegel B, Dickson VV. A situation-specific theory of heart failure self-care. Journal of Cardiovascular Nursing [Internet]. 2008 May;23(3):190-196. Available from: https://doi.org/10.1097/01.JCN.0000305091.35259.85

[10] Badir A. Chronic heart failure and care. In: Durna Z, editor. Chronic diseases and care. Istanbul, Turkey: Nobel Medical Bookstore; c2012. 147-160.

[11] Aydiner Boylu A, Paçacioğlu B. Quality of life and indicators. Journal of Academic Researches and Studies. 2016;8(15):137-150. Available from: https://doi.org/10.20990/kilisiibfakademik.266011

[12] Atik D. Quality of life in chronic diseases. In: Ovayolu N, Ovayolu Ö, editors. Basic Internal Diseases, Nursing and Chronic Diseases with Different Dimensions. Adana: Çukurova Nobel Medical Bookstore; c2017.

[13] Karakoç Kumsar A, Taşkın Yılmaz F. Overview of quality of life in chronic disease patients. Journal of Health Sciences Faculty of Erciyes University. 2014;2(2):62-70.

[14] Koçyiğit H, Aydemir Ö, Ölmez N. Reliability and validity of the turkish version of Short Form-36 (SF-36). Journal of Medicines and Treatment. 1999;12:102-106.

[15] Kearney BY, Fleischer BJ. Development of an instrument to measure exercise of self-care agency. Research in Nursing \& Health [Internet]. 1979 Mar;2(1):25-34. Available from: https://doi.org/10.1002/nur.4770020105

[16] Nahcivan N. The effect of self-care power and family environment on healthy young people. Istanbul: Istanbul University Health Science Institution; 1993.

[17] Alpar R. Applied Statistics and Validity-Reliability, 4th ed. Ankara: Detay Publishing; c2016.

[18] Heart Failure Road Map in Turkey. 2020. Available from: https://www.tkd.org.tr/Cg/007/Kyyolharitas1_151117.Pdf

[19] McMurray JJV, Adamopoulos S, Anker SD, Auricchio A, Bohm M, et al. ESC Guidelines for the diagnosis and treatment of acute and chronic heart failure 2012: The Task Force for the Diagnosis and Treatment of Acute and Chronic Heart Failure 2012 of the European Society of Cardiology. Developed in collaboration with the Heart Failure Association (HFA) of the ESC. European Heart Journal [Internet]. 2012;33(14):1787-1847. Available from: https://doi.org/10.1093/eurheartj/ehs 104

[20] Lei X, Cai M. Self-care ability and influencing factors in chronic heart failure patients. Biomedical Research [Internet]. 2018;29(3). Available from: https://doi.org/10.4066/biomedicalresearch.29-17-3205

[21] Conceição AP da, Santos MA dos, Santos B dos, Cruz D de ALM da. Self-care in heart failure patients. Revista Latino-Americana de Enfermagem [Internet]. 2015;23(4):578-586. Available from: https://doi.org/10.1590/0104-1169.0288.2591

[22] Harkness K, Heckman G, Jewett L, McKelvie R. Self-Care in heart failure index - do scores change over time? Canadian Journal of Cardiology [Internet]. 2013;29(10):S403-S404. Available from: https://doi.org/10.1016/j.cjca.2013.07.735

[23] Asgar Pour H, Gökçe S, Kunter D, Yönem H. Evaluation of self-care behaviours of patients with heart failure. Florence Nightingale Journal of Nursing [Internet]. 2016;24(2):66-71. Available from: https://doi.org/10.17672/fnhd.35274 
[24] Akbıyık A, Koçak G, Oksel E. Self-care behaviours analysis of patients with chronic heart failure. İzmir Kâtip Çelebi University Faculty Of Health Sciences Journal. 2016;1(2):1-8.

[25] Turkey Ministry of Health. Health and Health Protection Modules. Ankara: Ilkay Ofset Matbaacilik; 2008. Available from: https://sbu.saglik.gov.tr/Ekutuphane/Kitaplar/T6.Pdf

[26] Ermiş N. Self care agency and fatigue in patients with chronic heart failure. Journal of Cardiovascular Nursing [Internet]. 2018;9(20):105-112. Available from: https://doi.org/10.5543/khd.2019.30164

[27] Tegegn BW, Hussien WY, Abebe AE, Gebre MW. Adherence to self-care practices and associated factors among outpatient adult heart failure patients attending a Cardiac Center in Addis Ababa, Ethiopia in 2020. Patient Preference and Adherence [Internet]. 2021;15:317-327. Available from: https://doi.org/10.2147/PPA.S293121

[28] Bayrak B, Yıldırım G, Oğuz S, Sağaltıcı C, Doğanay E, Özdemir F, et al. Assessment of self-care in heart failure patients and determination of risk factors affecting. Journal of Cardiovascular Nursing [Internet]. 2019;10(23):114-121. Available from: https://doi.org/10.5543/khd.2019.68552

[29] Kessing D, Denollet J, Widdershoven J, Kupper N. Selfcare and health-related quality of life in chronic heart failure: a longitudinal analysis. European Journal of Cardiovascular Nursing [Internet]. 2017;16(7):605-613. Available from: https://doi.org/10.1177/1474515117702021

[30] Çeli Ktürk N, Durmaz Edeer A. Self-care agency and associated factors in heart transplant patients. Turkiye Klinikleri Cardiovascular Sciences [Internet]. 2019;31(3):148-154. Available from: https://doi.org/10.5336/cardiosci.2019-70586
[31] Dickson VV, Deatrick JA, Riegel B. A typology of heart failure self-care management in nonelders. European Journal of Cardiovascular Nursing [Internet]. 2008;7(3):171-181. Available from: https://doi.org/10.1016/j.ejcnurse.2007.11.005

[32] Seid MA. Health-related quality of life and extent of self-care practice among heart failure patients in Ethiopia. Health and Quality of Life Outcomes [Internet]. 2020;18(1):27. Available from: https://doi.org/10.1186/s12955-020-01290-7

[33] Özen B. Assessing correlation between health behaviors and life quality at cardiac insufficiency due to left ventricular systolic dysfunction. Istanbul: Halic University Health Sciences Institute; 2011.

[34] Mo Y, Chu M, Hu W, Wang H. Association between the nurse-led program with mental health status, quality of life, and heart failure rehospitalization in chronic heart failure patients. Medicine [Internet]. 2021;100(10):e25052. Available from: https://doi.org/10.1097/MD.0000000000025052

[35] Uslu H. Determination of anxiety-depression levels and quality of life in patients with heart failure and care givers. Antalya: Akdeniz University Institute of Health Sciences; 2011.

[36] Moss NE. Gender equity and socioeconomic inequality: a framework for the patterning of women's health. Social Science \& Medicine [Internet]. 2002;54(5):649-661. Available from: https://doi.org/10.1016/S02779536(01)00115-0

Received: $2021-02-25$

Revised: 2021-04-07

Accepted: 2021-04-14 